\title{
Retrieving Remotely Sensed Data Using Plank Algorithm in the Black Sea and Surrounding Seas (2008-2018)
}

\author{
Şeyma Merve Kaymaz Mühling (i) \\ Istanbul, Turkey \\ Email: seyma.merve87@gmail.com
}

How to cite this paper: Mühling, S. M. K. (2022). Retrieving Remotely Sensed Data Using Plank Algorithm in the Black Sea and Surrounding Seas (2008-2018). Journal of Geoscience and Environment Protection, 10, 65-77.

https://doi.org/10.4236/gep.2022.101005

Received: December 7, 2021

Accepted: January 10, 2022

Published: January 13, 2022

Copyright $\odot 2022$ by author(s) and Scientific Research Publishing Inc. This work is licensed under the Creative Commons Attribution International License (CC BY 4.0).

http://creativecommons.org/licenses/by/4.0/

\begin{abstract}
The Black Sea is the world's largest inner sea, its only connections with other seas being the Kerch Strait, which leads to the Azov Sea, and the Istanbul Strait, which connects it with the Mediterranean Sea. The main aim of this study processes to image analysis and applied algorithm, to retrieve remote SST data from satellite, to assess the estimated SSTs, to understand the characteristics of SST by presenting in the Black Sea and surrounding seas, to discuss the SSTs changes according to climate change impacts. In this study, Landsat 7 and Landsat 8 Operational Land Imager (OLI)/Thermal Infrared Sensor (TIRS) Level-1 images of TIR bands are used to predict Sea Surface Temperature (SST) changes using the Plank algorithm in the Black Sea and surrounding seas between 2008 and 2018. The SST values were taken from 55 different stations chosen from the study area. The SST result presented the central months of the four hydrological seasons. The increasing temperature data were supported by the literature studies that alien invasive species entered the Black Sea. The climatic fluctuations obtained as a result of this study will increase the invasion level of non-native species and their invasion will continue into the Black Sea and surrounding seas.
\end{abstract}

\section{Keywords}

Black Sea, SST, Invasive Species, Mediterranization

\section{Introduction}

The temperature is a key parameter on the physical, chemical and biological features of the marine environment. Therefore, temperature data play a significant role in a wide range of environmental resources management activities (Lillesand \& Kiefer, 1987; EPA, 2016; NOAA, 2016). Sea surface temperature 
(SST) is a vital parameter in the context of biodiversity in marine environments (Wloczyk et al., 2006). SST is needed to study predictions of marine protected areas, climate change, sea-level rise, pollution estimations. Satellite technologies provide to evaluate information (the brightness values) from a distance that understands changes in the seas for more than 40 years (Bartolucci et al., 1988; Lillesand \& Kiefer, 1987; Tarigan \& Wouthuyzen, 2017). This makes SST a very valuable indicator for the marine studies. Increasing amounts of greenhouse gases into the atmosphere due to climate warming are the main reason for the rising SST levels (Tseng et al., 2011; Hoegh-Guldberg \& Bruno, 2010; EPA, 2016; NAC, 2014). The significant reason for considering the SST changes is that to take precautions against potential impacts on marine life and living organism (Ostrander et al., 2010; Deser et al., 2010; IPCC, 2011).

The SST retrieval using brightness temperatures of satellites sensors was based on multi-channel algorithms in the early 1970's (Anding \& Kauth, 1970; Prabhakara et al., 1974). Landsat satellites are operated by the Earth Observation Program of the National Aeronautics and Space Administration (NASA) for coastal regions. The first Landsat satellite was launched in 1972. Also, Landsat 1 was developed and improved the sensors and the technology in 1972 to Landsat 8 in 2013. Currently, the Landsat 7 Enhanced Thematic Mapper Plus (ETM+) and the Landsat 8 Operational Land Imager and Thermal Infrared Sensor (OLI/TIRS) are in operation (Ranagalage et al., 2017). In remote sensing, to predict the surface temperature, it is necessary that satellite images have convenient spatio-temporal resolution. The surface temperature is retrieval by the radiative transfer equation method using thermal bands of remotely sensed images. The computation of Sea Surface Temperature (SST) is obtained using thermal infrared data sets since the 1970s. And this development improved measurements tool and increased the accuracy of the computation (Alavipanah, 2006).

In recent years, different algorithms have been derived from satellite images for the prediction of sea surface temperatures. These algorithms are based on assumptions and approximations variety of radiation equation (Li et al., 2013).

This study ensured an information content analysis for the Landsat thermal bands using the Plank method with ArcGIS software. Also, previous studies with similar objectives did not address the entire Black Sea and surrounding seas using the Plank method. The main purposes of this paper are to retrieve remote SST data, to assess the estimation and analyse the trends of the SST, to understand the characteristics of SST by presenting in the Black Sea and surrounding seas, to discuss the SSTs changes according to climate change impacts.

\section{Data Analysis}

\subsection{Study Area}

The Black Sea is the world's largest inner sea, its only connections with other seas being the Kerch Strait, which leads to the Azov Sea, and the Istanbul Strait, which connects it with the Mediterranean Sea (Blatov et al., 1984; Ivanov \& Be- 
lokopytov, 2013).

As the Black Sea is an inner sea, its sea surface temperature is less parallel to the air temperature. The regional and seasonal differences in the sea surface temperature of the Black Sea are higher than in other seas (Büyükhatipoğlu et al., 2002).

The Black Sea has weak vertical mixing due to peculiarities of its density stratification. Because of the low density of its upper mixed layer, its air temperature and sea surface temperature (SST) react rapidly to atmospheric and climate forces. Therefore, the Black Sea SST is exposed to important periodical, synoptic and interannual changes (Blatov et al., 1984; Altman et al., 1987). Sea surface temperature regulates the sea-air heat exchange and impacts circulation (Staneva et al., 1998; Gregoire et al., 1998).

The Black Sea changed significantly through impacts of climate change, eutrophication, overfishing, and increase in biomass of gelatinous and adaptable species. These effects were studied potently throughout the last two decades (Murray, 1991; Oguz \& Ediger, 2006).

This paper presents results on sea surface temperatures over the Black Sea and surrounding seas on time scales ranging from 2008 to 2018.

\subsection{Remote Sensed SST Data}

In this study, Landsat7 and Landsat 8 Operational Land Imager (OLI)/Thermal Infrared Sensor (TIRS) Level-1 images of TIR bands are used to predict Sea Surface Temperature (SST) changes in the Black Sea together with the Sea of Azov. The TIR bands (B10 and B11) are defined with thermal infrared spectrum at the wavelength with a $30 \mathrm{~m}$ spatial resolution after the resampling process (Acharya \& Yang, 2015).

Landsat data (Level 1) products consist of quantized and calibrated scaled Digital Numbers (DN) that can be rescaled to the top of atmosphere (TOA) reflectance or radiance using radiometric rescaling factors and thermal constants used to convert thermal band data to TOA brightness temperature (BT). These coefficients and the image characteristics are provided in the metadata file (MTL.txt) of the bands. Level 1 images are in GeoTIFF format were calibrated (Pinto et al., 2020; USGS, 2015).

The estimation of SST analysis was started with image pre-processing atmospheric and radiometric correction via top-of-atmosphere (TOA) spectral radiance values (1) using the rescaling factors with ArcGIS 10.6 software.

$$
\mathrm{L} \lambda=\mathrm{ML} \cdot \mathrm{Qcal}+\mathrm{AL}
$$

where:

$\mathrm{L} \lambda=$ TOA spectral radiance $\left(\right.$ Watts $\left./\left(\mathrm{m}^{2 *} \operatorname{srad}^{\star} \mu \mathrm{m}\right)\right)$;

$\mathrm{ML}=$ Band-specific multiplicative rescaling factor;

$\mathrm{AL}=$ Band-specific additive rescaling;

Qcal $=$ Q.

The radiance value of images are converted into Brightness Temperature 
value by using Plank algorithm (2):

$$
\mathrm{Ts}=\mathrm{BT} /(1+(\lambda \cdot \mathrm{BT} / \rho) \cdot \ln \varepsilon)
$$

where:

$$
\begin{aligned}
& \mathrm{T}_{s}=\mathrm{SST} \text { in Kelvin }(\mathrm{K}) ; \\
& \mathrm{BT}=\text { Brightness Temperature at sensor }(\mathrm{K}) ; \\
& \lambda=\text { wavelength; } \\
& \rho=\left(\mathrm{h}{ }^{*} \mathrm{c} / \sigma\right)=1.438 \times 10^{-2} \mathrm{mK} ; \\
& \varepsilon=\text { spectral emissivity (Isaya Ndossi, \& Avdan, 2016). }
\end{aligned}
$$

The SST temperature value in Kelvin $(\mathrm{K})$ is converted to temperature in Celcius using the Equation (3):

$$
\mathrm{T}^{\circ} \mathrm{C}=\mathrm{T}(\mathrm{K})-273
$$

The Landsat 7 and 8 OLI/TIRS images are obtained from the USGS/Earth Explorer portal for the four seasons (February-May-August-November) during the periods of 2008 to 2018.

The research of annual temperature changes of the Black Sea is particularly significant for consideration of climate change (Strong, 1989; Levitus et al., 2000).

The 11 yearly (2008-2018) mean SST fields for the central months of four hydrological seasons (spring: May, summer: August, autumn: November, winter: February) are presented in "Figure 1". The SST values were taken from 55 different stations chosen from the Black sea.

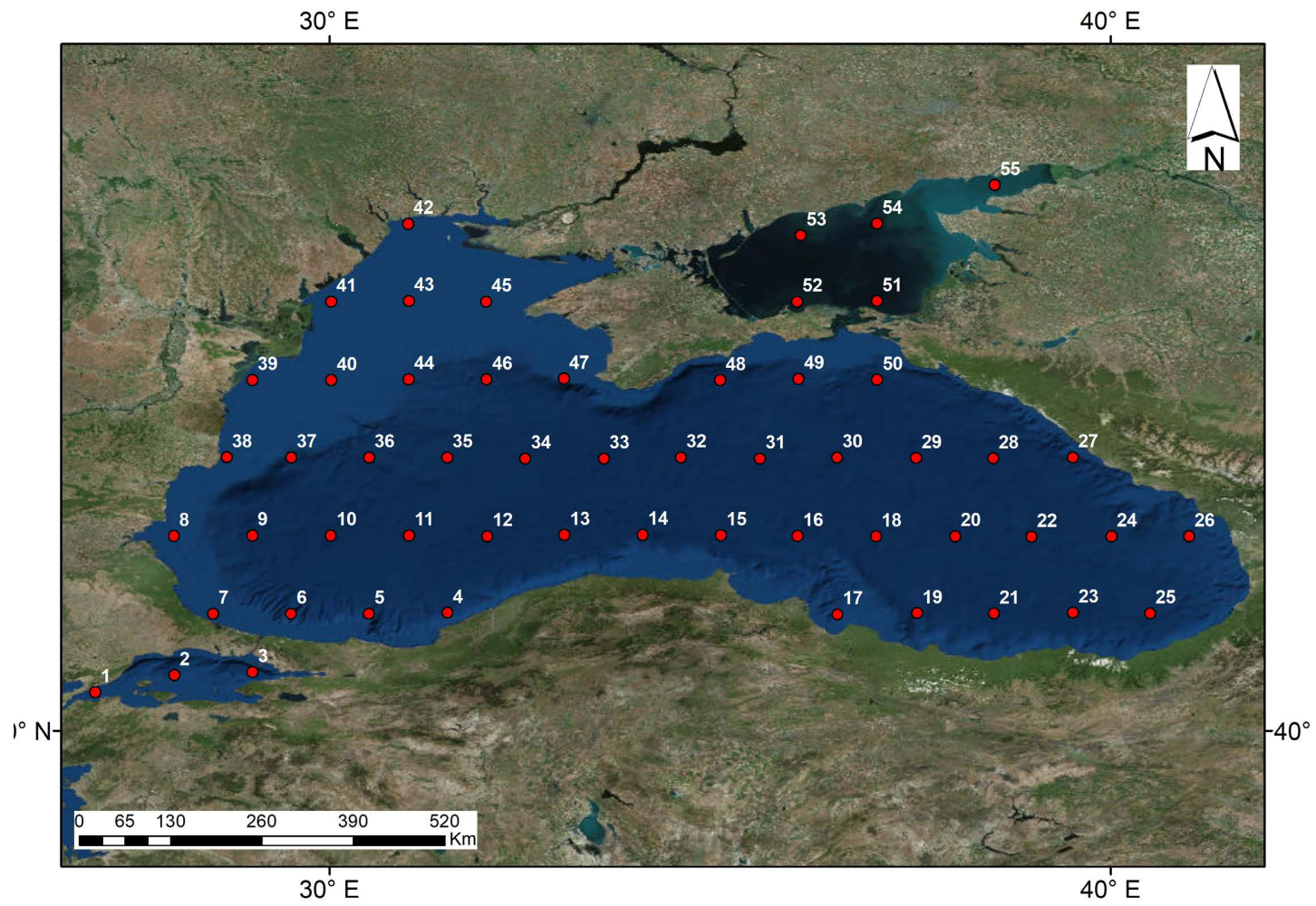

Figure 1. Study area. 


\section{Results}

Between 2008 and 2018, seasonal data were retrieved from satellite images in selected stations using GIS and remote sensing programmes. The data were then processed using the STAT 10 programme. The lowest value was measured as $5.78^{\circ} \mathrm{C}$ in February 2012. The highest value was measured as $29.20^{\circ} \mathrm{C}$ in August 2010 (“Table 1”).

Table 1. SST mean values between 2008 and 2018 .

\begin{tabular}{|c|c|c|c|c|c|c|}
\hline Year & Month & $\operatorname{SST}\left({ }^{\circ} \mathrm{C}\right)$ mean & SST Std. error & SST -95.00\% & SST $+95.00 \%$ & $\mathrm{~N}$ \\
\hline 2008 & February & 6.02854 & 0.222839 & 5.58178 & 6.47531 & 55 \\
\hline 2008 & May & 14.31982 & 0.089099 & 14.14118 & 14.49845 & 55 \\
\hline 2008 & August & 25.49891 & 0.087912 & 25.32266 & 25.67516 & 55 \\
\hline 2008 & November & 14.75927 & 0.268716 & 14.22053 & 15.29801 & 55 \\
\hline 2009 & February & 7.69836 & 0.239680 & 7.21783 & 8.17889 & 55 \\
\hline 2009 & May & 14.93273 & 0.156065 & 14.61984 & 15.24562 & 55 \\
\hline 2009 & August & 24.08564 & 0.099094 & 23.88696 & 24.28431 & 55 \\
\hline 2009 & November & 14.32673 & 0.280376 & 13.76461 & 14.88885 & 55 \\
\hline 2010 & February & 7.62636 & 0.222684 & 7.17991 & 8.07282 & 55 \\
\hline 2010 & May & 17.24455 & 0.148017 & 16.94779 & 17.54130 & 55 \\
\hline 2010 & August & 29.20964 & 0.093107 & 29.02297 & 29.39630 & 55 \\
\hline 2010 & November & 15.14055 & 0.199380 & 14.74081 & 15.54028 & 55 \\
\hline 2011 & February & 7.42800 & 0.241002 & 6.94482 & 7.91118 & 55 \\
\hline 2011 & May & 13.60073 & 0.100328 & 13.39958 & 13.80187 & 55 \\
\hline 2011 & August & 24.58527 & 0.168949 & 24.24655 & 24.92400 & 55 \\
\hline 2011 & November & 11.44273 & 0.285544 & 10.87025 & 12.01521 & 55 \\
\hline 2012 & February & 5.78182 & 0.243453 & 5.29373 & 6.26991 & 55 \\
\hline 2012 & May & 17.70964 & 0.202229 & 17.30419 & 18.11508 & 55 \\
\hline 2012 & August & 25.90345 & 0.138214 & 25.62635 & 26.18056 & 55 \\
\hline 2012 & November & 15.75545 & 0.251133 & 15.25196 & 16.25895 & 55 \\
\hline 2013 & February & 7.18727 & 0.261471 & 6.66306 & 7.71149 & 55 \\
\hline 2013 & May & 17.65691 & 0.135205 & 17.38584 & 17.92798 & 55 \\
\hline 2013 & August & 26.32836 & 0.066084 & 26.19587 & 26.46085 & 55 \\
\hline 2013 & November & 14.32345 & 0.232898 & 13.85652 & 14.79039 & 55 \\
\hline 2014 & February & 8.26164 & 0.252675 & 7.75505 & 8.76822 & 55 \\
\hline 2014 & May & 15.75873 & 0.151218 & 15.45555 & 16.06190 & 55 \\
\hline 2014 & August & 27.78582 & 0.081147 & 27.62313 & 27.94851 & 55 \\
\hline 2014 & November & 13.62673 & 0.319974 & 12.98522 & 14.26824 & 55 \\
\hline 2015 & February & 7.23363 & 0.263178 & 6.70599 & 7.76127 & 55 \\
\hline 2015 & May & 16.29455 & 0.091862 & 16.11037 & 16.47872 & 55 \\
\hline
\end{tabular}




\begin{tabular}{|c|c|c|c|c|c|c|}
\hline \multicolumn{7}{|c|}{ Continued } \\
\hline 2015 & August & 26.70691 & 0.116405 & 26.47353 & 26.94029 & 55 \\
\hline 2015 & November & 14.24036 & 0.268852 & 13.70135 & 14.77938 & 55 \\
\hline 2016 & February & 8.29800 & 0.260070 & 7.77659 & 8.81941 & 55 \\
\hline 2016 & May & 16.39145 & 0.109197 & 16.17253 & 16.61038 & 55 \\
\hline 2016 & August & 26.21673 & 0.188877 & 25.83805 & 26.59540 & 55 \\
\hline 2016 & November & 13.87291 & 0.300629 & 13.27018 & 14.47563 & 55 \\
\hline 2017 & February & 6.21946 & 0.224140 & 5.77008 & 6.66883 & 55 \\
\hline 2017 & May & 14.49400 & 0.141654 & 14.21000 & 14.77800 & 55 \\
\hline 2017 & August & 26.39182 & 0.174348 & 26.04227 & 26.74136 & 55 \\
\hline 2017 & November & 14.32982 & 0.246778 & 13.83506 & 14.82458 & 55 \\
\hline 2018 & February & 8.03673 & 0.277266 & 7.48084 & 8.59261 & 55 \\
\hline 2018 & May & 17.07909 & 0.119085 & 16.84034 & 17.31784 & 55 \\
\hline 2018 & August & 25.29927 & 0.141208 & 25.01617 & 25.58238 & 55 \\
\hline 2018 & November & 15.23655 & 0.322133 & 14.59071 & 15.88238 & 55 \\
\hline
\end{tabular}

According to spatial mapping analysis, the results were as follows. For February, the lowest value was $0.54^{\circ} \mathrm{C}$ in 2008 and the highest value was $11.32^{\circ} \mathrm{C}$ in 2018 ("Figure 2"). For May, the lowest value was $10.77^{\circ} \mathrm{C}$ in 2011 and the highest value was $24.33^{\circ} \mathrm{C}$ in 2012 ("Figure 3"). For August, the lowest value was $20.8^{\circ} \mathrm{C}$ in 2009 and the highest value was $30.62^{\circ} \mathrm{C}$ in 2010 ("Figure 4"). For November, the lowest value was $2.14^{\circ} \mathrm{C}$ in 2011 and the highest value was $18.89^{\circ} \mathrm{C}$ in 2012 ("Figure 5").

A total of 55 sampling points were used to measure the SST remote sensed with the Landsat processed data. The study used the thermal bands to retrieve SST based on the Plank method. The elaborated algorithm allowed to estimate SST from the Landsat 7 and 8 data for the Black Sea between 2008 and 2018. "Figure 6" shows that SST data were modelled as linear. In other words, the SST values increase gradually in the four seasons.

\section{Discussion}

The Black Sea is an almost closed sea that has limited interaction with the Mediterranean Sea and the Turkish Straits. Circulation is mainly cyclonic in the Black Sea and usually driven through surface fluxes and freshwater input from the Danube, Dnieper and Dniester rivers. Synoptic wind stress plays an unimportant role for the circulation in the Black Sea.

On the contrary the Mediterranean Sea, there is excess rainfall over evaporation in an average year, the situation equalled by outflow from the Black Sea to the Aegean Sea through the Turkish Straits.

For the spatio-temporal distribution of surface sea temperature in the Black Sea, the most outstanding feature is its growth in the route from northwest to southeast in all seasons. This is because of the common atmospheric conditions 

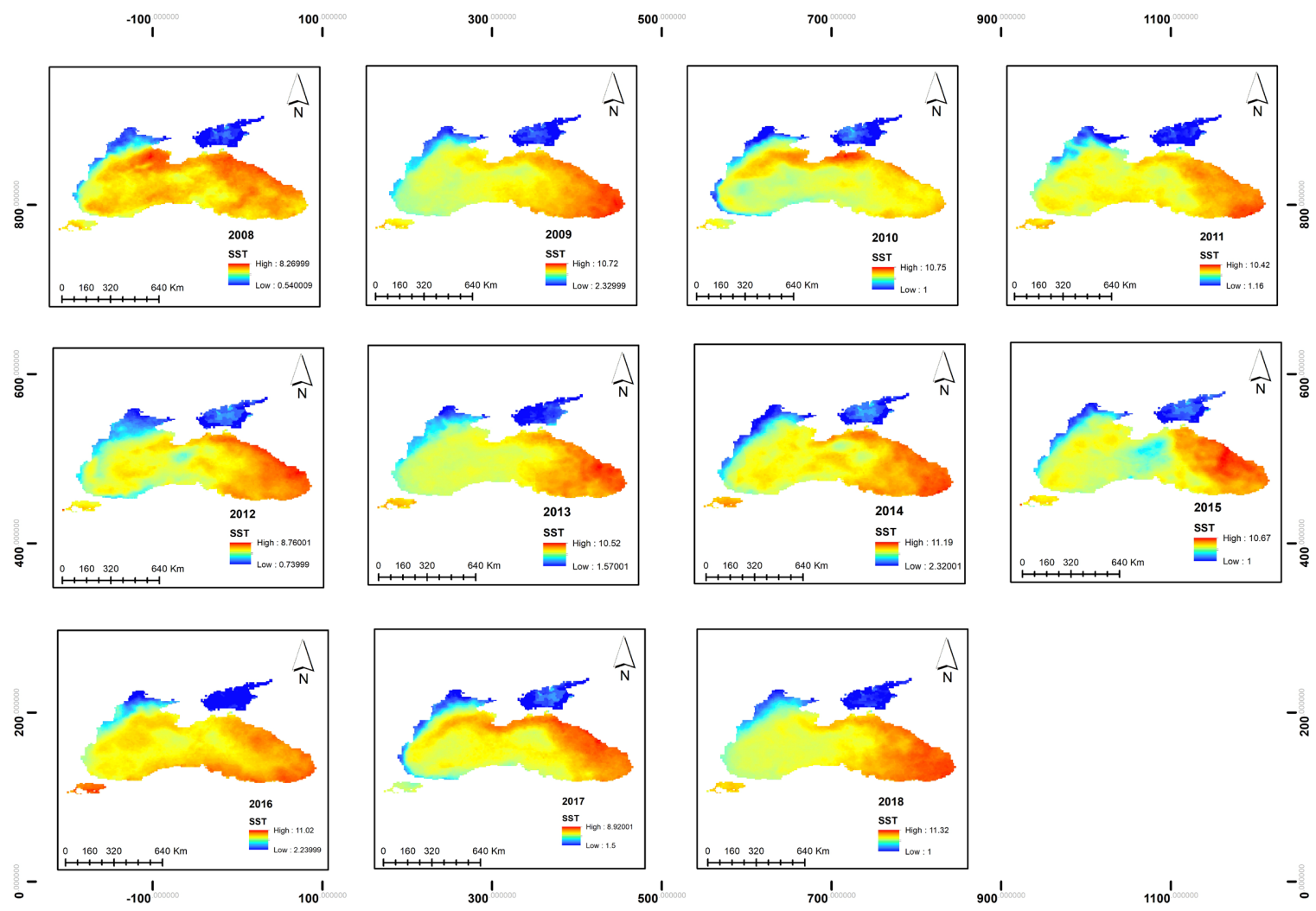

Figure 2. Spatial SST Map for February between 2008 and 2018.
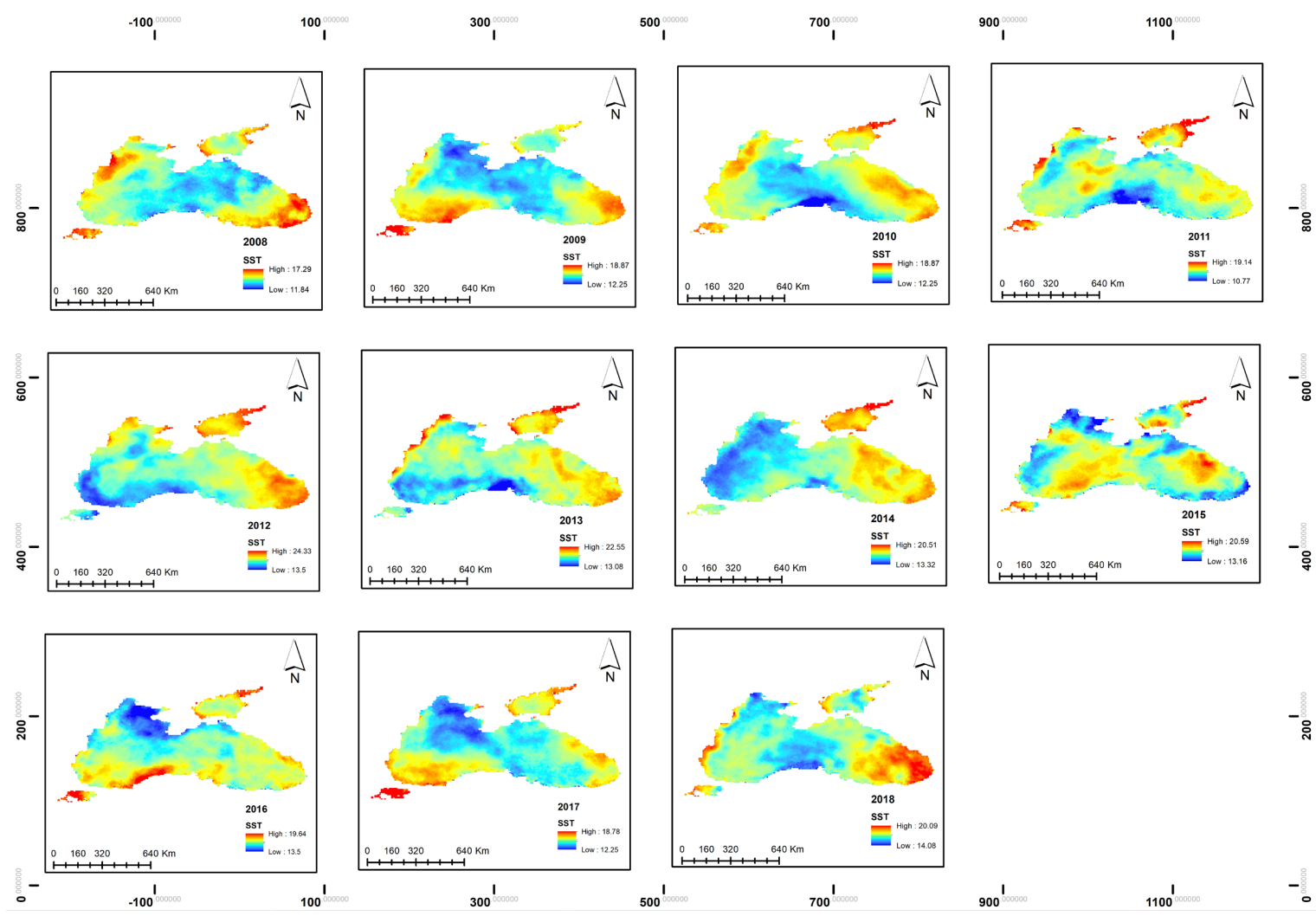

Figure 3. Spatial SST Map for May between 2008 and 2018. 

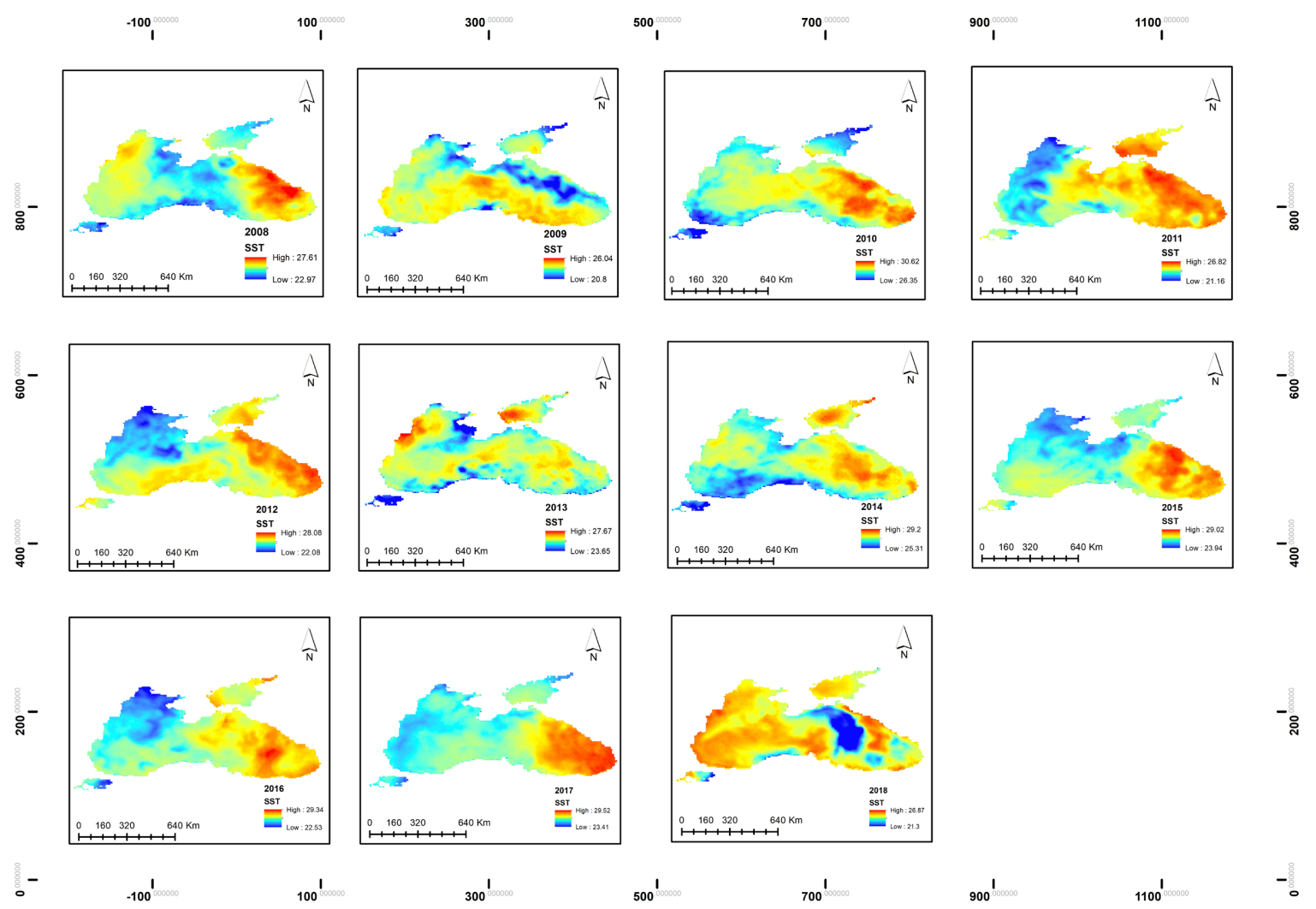

500
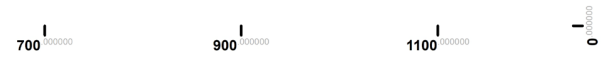

Figure 4. Spatial SST Map for August between 2008 and 2018.
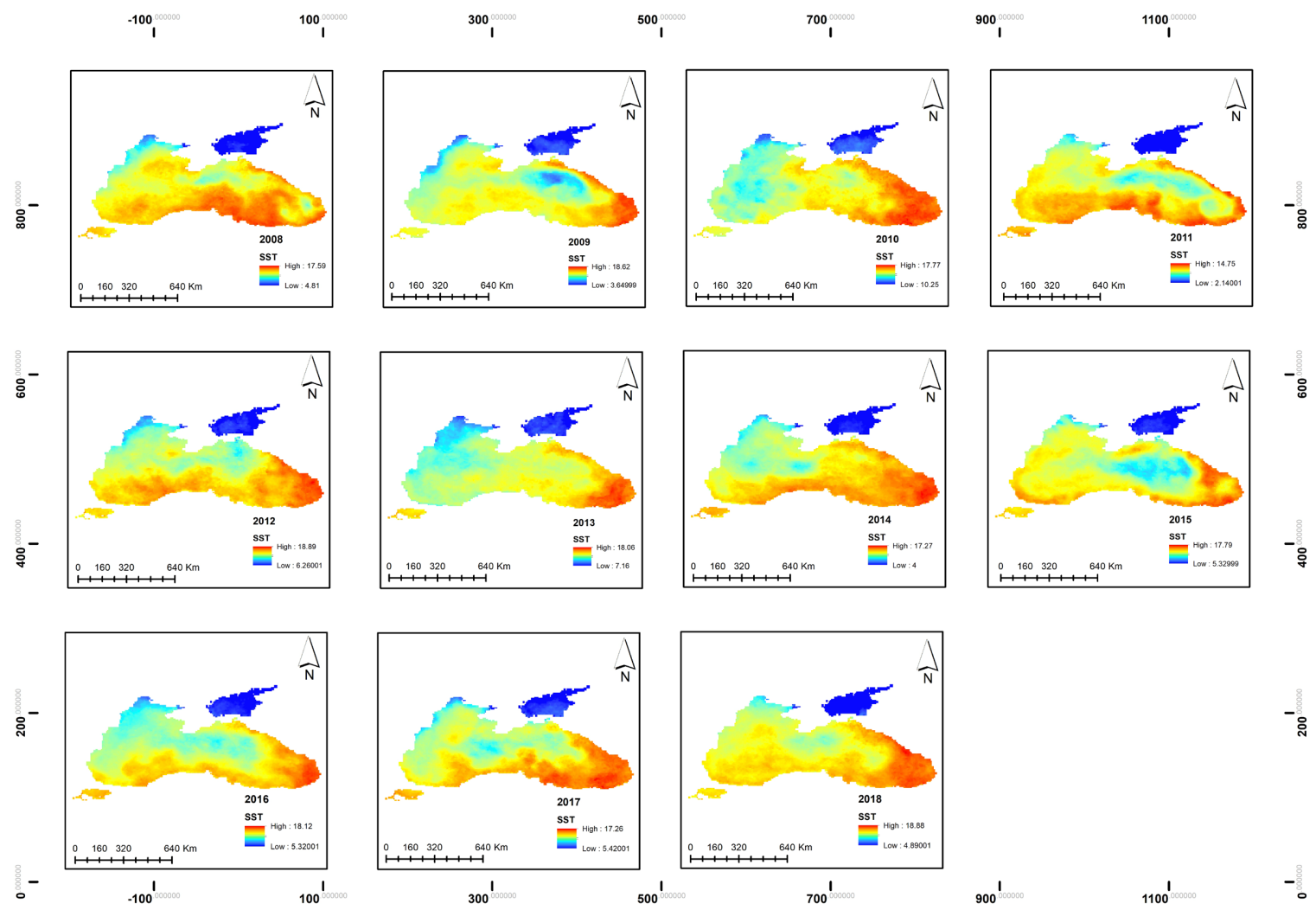

Figure 5. Spatial SST Map for November between 2008 and 2018. 


\section{Sea Surface Temperature $\left({ }^{\circ} \mathrm{C}\right)$}

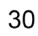

30

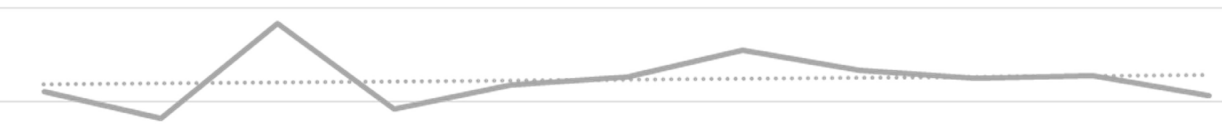

20

15

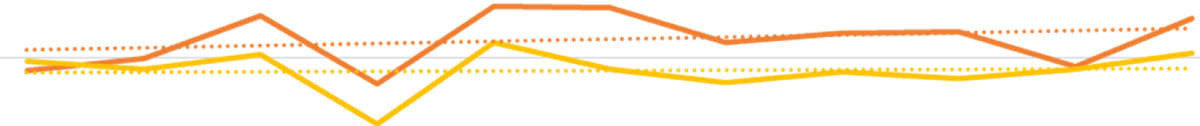

10

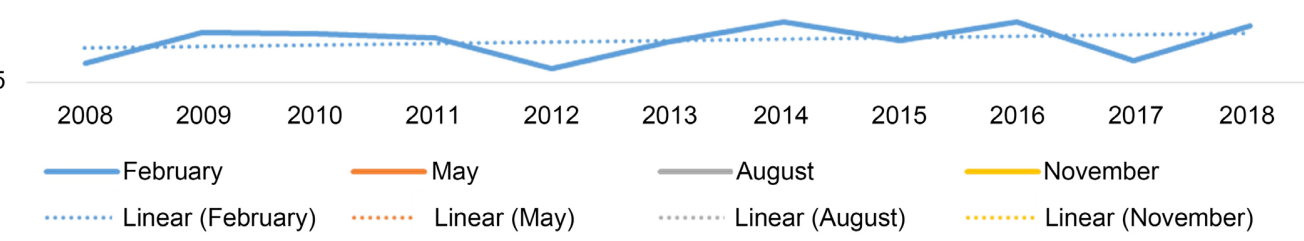

Figure 6. The graph of SST changes between 2008 and 2018.

in the area: the climate in the north-west of the Black Sea is mild, while it is more subtropical in the eastern part of the Black Sea.

In winter season, low water temperatures are not restricted to the north-west, but also occur in the central part of the Black Sea, due to the extreme cooling of the surface layer in the centers of cyclonic gyres ("Figure 7"). The spatial contrasts of sea temperature are most recognizable in winter ("Figure 2"). In spring ("Figure 3") and summer ("Figure 4"), they are significantly smoothed.

The sea surface temperature is lowest on the northern, Ukrainian and Russian coasts in February. The temperature is highest in the cyclonic gyres of the Eastern, Batumi and Caucasus areas in August.

In February ("Figure 3"), warm waters distribute from the eastern to the western part and cold waters distribute from the north eastern region along the western and southern coasts (Blatov et al., 1984; Simonov \& Altman, 1991; Özsoy \& Ünlüata, 1997). This concurs with the satellites SST distribution for February and March presented in "Figure 2" and "Figure 5".

The climate changes are explained with fluctuations in the Atlantic multidecadal Oscillation index reported in the Black Sea region by Oğuz et al. (2006), Ilyin (2010), and Polonsky et al. (2013). The changing climate probably accelerated the invasion process in the Black sea. In addition, the Turkish Straits are the main transit corridors for invasive species in the Black Sea (Georgieva, 1993; Kovalev, 2006; Selifinova et al., 2008; Jakubova, 1948). The increase in temperature creates new habitats for alien and invasive species. The invasion of the Black Sea by new Mediterranean species and Mediterranization will continue by rise in temperature as a consequence of climate change (Oğuz, 2005; Öztürk, 2021). For fish, the number of alien species were 28 ( 4 alien and 24 new Mediterranean species) in the western and 16 ( 2 alien and 14 new Mediterranean fish species) in the eastern Black sea (Shalovenkov, 2019). This increase in the number of alien species could be in consequence of climate changes. 


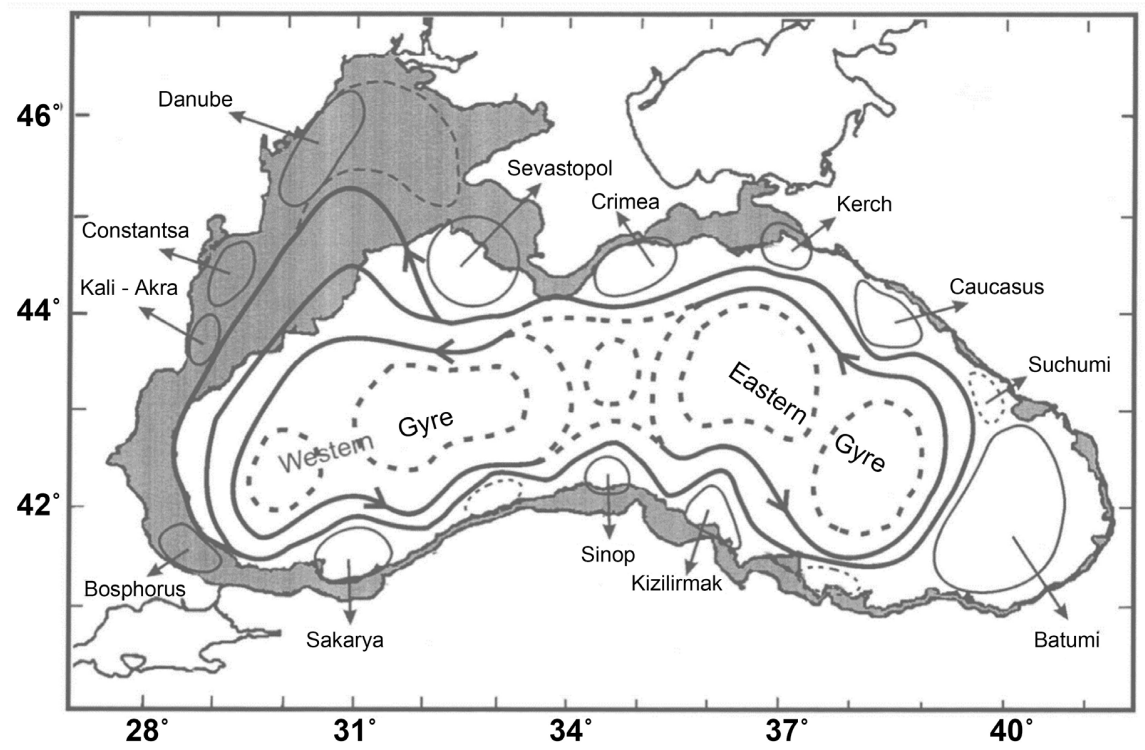

Figure 7. General circulation of Sea surface current in the Black sea (Oguz et al., 2005; Ivanov \& Belokopytov, 2013).

\section{Conclusion}

The climatic fluctuations obtained as a result of this study will increase the invasion level of non-native species and their invasion will continue into the Black Sea. With the increase in SST, it seems likely that the invasion of alien species can increase from the Indo-pacific region. International studies should be continued and monitoring studies should be intensified.

This kind of remote sensed data studies enables an increased awareness, better understanding of the issues and risks as well as options for future actions in the Black Sea. However, the results of these studies must also be supported by in-situ measurements.

\section{Acknowledgements}

Many thanks to USGS earth explorer present the satellite data for free to the World.

\section{Conflicts of Interest}

The author declares no conflicts of interest regarding the publication of this paper.

\section{References}

Acharya, D. T., \& Yang, I. (2015). Exploring Landsat 8. International Journal of IT, Engineering and Applied Sciences Research, 4, 4-10.

Alavipanah, S. K. (2006). Thermal Remote Sensing and Its Application in the Earth Sciences (2nd ed., p. 1387). University of Tehran.

Altman, E. N., Gertman, I. F., \& Golubeva, Z. A. (1987). Climatic Fields of the Black Sea Water Salinity and Temperature (107 p.). GOIN Sevastopol Branch. 
Anding, D., \& Kauth, R. (1970). Estimation of Sea Surface Temperature from Space. Remote Sensing of Environment, 1, 217-220. https://doi.org/10.1016/S0034-4257(70)80002-5

Bartolucci, L. A., Chang, M., Anuta, P. E., \& Graves, M. R. (1988). Aton Landsat TM Thermal Infrared Data. IEEE Transactions on Geoscience and Remote Sensing, 8, 1509-1522.

Blatov, A. S., Bulgakov, N. P., Ivanov, V. A., Kosarev, A. N., \& Tuzhilkin, V. S. (1984). Variability of Hydrophysical Fields of the Black Sea (240 p.). Gidrometeoizdat.

Büyükhatipoğlu, S., Bat, L., Kideys, A. E., Tugrul, S., Zagorodnyaya, J., Gündogdu, A., \& Satilmis, H. H. (2002). Orta Karadeniz’in Sinop Burnu Bölgesinin Biyokimyasal Dönüsüm Çalismalari. TÜBITAK Proje No. YDABÇAG-619/G 197Y156. 92s.

Deser, C., Phillips, A., \& Alexander, M. (2010). Twentieth Century Tropical Sea Surface Temperature Trends Revisited. Geophysical Research Letters, 37, L10701. https://doi.org/10.1029/2010GL043321

EPA (2016). Climate Change Indicators: Sea Surface Temperature. United States Environmental Protection Agency.

Georgieva, L. V. (1993). Species Composition and Dynamics of Phytocoenosis. In A. V. Kovalev, \& Z. Z. Finenko (Eds.), Plankton of the Black Sea (pp. 31-74). Naukova Dumka. (In Russian)

Gregoire, M., Beckers, J. M., Nihoul, J. C. J., \& Stanev, E. (1998). Reconnaissance of the Black Sea's Ecohydrodynamics by Means of a 3D Interdisciplinary Model. Journal of Marine System, 16, 85-105. https://doi.org/10.1016/S0924-7963(97)00101-2

Hoegh-Guldberg, O., \& Bruno, J. F. (2010). The Impact of Climate Change on the World's Marine Ecosystems. Science, 328, 1523-1528.

https://doi.org/10.1126/science.1189930

Ilyin, Y. P. (2010). Climatic Variability of Salinity Features on the Bosporus and North-Western Shelves Revealed from Observational Data. Journal of Environmental Protection Ecology, 11, 993-1000.

https://docs.google.com/a/jepe-journal.info/viewer?a=v\&pid=sites\&srcid=amVwZS1qb 3VybmFsLmluZm98amVwZS1qb3VybmFsfGd4OjZkZmQ0Zjc2ZjU5ODAwZGE

Intergovernmental Panel on Climate Change (IPCC), IPCC Special Report on Renewable Energy Sources and Climate Change Mitigation IPCC (2011). https://www.ipcc.ch/site/assets/uploads/2018/03/SRREN Full Report-1.pdf

Ivanov, V. A., \& Belokopytov, V. N. (2013). Oceanography of the Black Sea (210 p.). National Academy of Sciences of Ukraine, Marine Hydrophysical Institute. (In English)

Jakubova, L. I. (1948). Features of Biology near the Bosporus Site of the Black Sea. Proceeding Sevastopol Biological Station, 6, 274-285.

Kovalev, A. V. (2006). On the Problem of Lessepsian Migrations of Zooplanktonic Organisms. Mediterranean Marine Science, 7, 67-71. https://doi.org/10.12681/mms.171

Levitus, S., Antonov, J. I., Boyer, T. P., \& Stephens, C. (2000). Warming of the World Ocean. Science, 287, 2225-2229. https://doi.org/10.1126/science.287.5461.2225

Li, Z.-L., Wu, H., Wang, N., Qiu, S., Sobrino, J. A., Wan, Z., Tang, B.-H., \& Yan, G. (2013). Land Surface Emissivity Retrieval from Satellite Data. International Journal of Remote Sensing, 34, 3084-3127. https://doi.org/10.1080/01431161.2012.716540

Lillesand, T. M., \& Kiefer, R. W. (1987). Remote Sensing and Image Interpretation (736 p.). John Wiley \& Sons.

Murray, J. W. (1991). Black Sea Oceanography: Results from the 1988 Black Sea Expedition: Introduction and summary. Deep-Sea Research Part A. Oceanographic, 38, 
S661-S665. https://doi.org/10.1016/S0198-0149(10)80002-0

National Climate Assessment (NAC) (2014). Report Findings: Oceans. http://nca2014.globalchange.gov/highlights/report-findings/oceans

National Oceanic and Atmospheric Administration (NOAA) (2016). NOAA Merged Land Ocean Global Surface Temperature Analysis (NOAAGlobalTemp): Global Gridded $5^{\circ} \times 5^{\circ}$ Data. National Centers for Environmental Information. https://www.ncdc.noaa.gov/data-access/marineocean-data/mlost

Ndossi, M. I., \& Avdan, U. (2016). Application of Open Source Coding Technologies in the Production of Land Surface Temperature (LST) Maps from Landsat: A PyQGIS Plugin. Remote Sensing, 8, 413. https://doi.org/10.3390/rs8050413

Oğuz, T. (2005). Black Sea Ecosystem Response to Climatic Teleconnections. Oceanography, 18, 122-133. https://doi.org/10.5670/oceanog.2005.47

Oguz, T., \& Ediger, D. (2006). Comparision of in Situ and Satellite-Derived Chlorophyll Pigment Concentrations, and Impact of Phytoplankton Bloom on the Suboxic Layer Structure in the Western Black Sea during May-June 2001. Deep-Sea Research, 53, 1923-1933. https://doi.org/10.1016/j.dsr2.2006.07.001

Oğuz, T., Dippner, J. W., \& Kaymaz, Z. (2006). Climatic Regulation of the Black Sea Hydro-Meteorological and Ecological Properties at Interannual-to-Decadal Time Scales. Journal of Marine Systems, 60, 235-254. https://doi.org/10.1016/j.jmarsys.2005.11.011

Oguz, T., Tugrul, S., Kideys, A. E., Ediger, V., \& Kubilay, N. (2005). Chapter 33. Physical and Biogeochemical Characteristics of the Black Sea. In A. R. Robinson, \& K. H. Brink (Eds.), The Sea (Vol. 14, pp. 1331-1369). President and Fellows of Harvard College.

Ostrander, G. K., Armstrong, K. M., Knobbe, E. T., Gerace, D., \& Scully, E. P. (2010). Rapid Transition in the Structure of a Coral Reef Community: The Effects of Coral Bleaching and Physical Disturbance. Proceedings of the National Academy of Sciences of the United States of America, 97, 5297-5302. https://doi.org/10.1073/pnas.090104897

Özsoy, E., \& Ünlüata, Ü. (1997). Oceanography of the Black Sea: A Review of Some Recent Results. Earth-Science Reviews, 42, 231-272. https://doi.org/10.1016/S0012-8252(97)81859-4

Öztürk, B. (2021). Non-Indigenous Species in the Mediterranean and the Black Sea. Studies and Reviews No. 87 (General Fisheries Commission for the Mediterranean). FAO.

Pinto, C. T., Jing, X., \& Leigh, L. (2020). Evaluation Analysis of Landsat Level-1 and Level-2 Data Products Using in Situ Measurements. Remote Sensing, 12, 2597. https://doi.org/10.3390/rs12162597

Polonsky, A. B., Shokurova, I. G., \& Belokopytov, V. N. (2013). Decadal Variability of Temperature and Salinity in the Black Sea. Marine Hydrophysical Journal, 6, 27-41.

Prabhakara, C., Dalu, G., \& Kunde, V. G. (1974). Estimation of Sea Surface Temperature from Remote Sensing in the 11- to 13- $\mu \mathrm{m}$ Window Region. Journal of Geophysical Research, 79, 5039-5044. https://doi.org/10.1029/JC079i033p05039

Ranagalage, M., Estoque, R. C., \& Murayama, Y. (2017). An Urban Heat Island Study of the Colombo Metropolitan Area, Sri Lanka, Based on Landsat Data (1997-2017). ISPRS International Journal of Geo-Information, 6, 189. https://doi.org/10.3390/ijgi6070189

Selifinova, J., Shmeleva, A., \& Kideys, A. (2008). Study of Copepod Species from the Western Black Sea in the Cruise r/v "Knorr" during May-June 2001. Acta Zoologica Bulgarica, 60, 305-309.

Shalovenkov, N. (2019). Alien Species Invasion: Case Study of the Black Sea. In Coasts and Estuaries: The Future (pp. 547-568). Elsevier. 
https://doi.org/10.1016/B978-0-12-814003-1.00031-9

Simonov, A. I., \& Altman, E. N. (1991). Hydrometeorology and Hydrochemistry of Seas in the USSR, Vol. IV. Black Sea. Issue 1. Hydrometeorological Conditions (429 p.). Gidrometeoizdat.

Staneva, J. V., Stanev, E. V., \& Oguz, T. (1998). The Impact of Atmospheric Forcing and Water Column Stratification on the Yearly Plankton Cycle. In L. I. Ivanov, \& T. Oguz (Eds.), Ecosystem Modeling as s Management Tool for the Black Sea (Vol. 2, pp. 301-322). Kluwer Academic Publishing.

Strong, A. E. (1989). Greater Global Warming Revealed by Satellite Derived Sea-Surface Temperature Trends. Nature, 338, 642-645. https://doi.org/10.1038/338642a0

Tarigan, S., \& Wouthuyzen, S. (2017). Mapping and Monitoring the Sea Surface Temperature in Weda Bay Using Terra and Aqua-Modis Satellites. Journal of Remote Sensing and GIS, 6, 4. https://doi.org/10.4172/2469-4134.1000217

TOA.

https://www.usgs.gov/core-science-systems/nli/landsat/using-usgs-landsat-level-1-data -product

Tseng, C. T., Sun, C. L., Yeh, S. Z., Chen, S. C., Su, W. C., \& Liu, D. C. (2011). Influence of Climate-Driven Sea Surface Temperature Increase on Potential Habitats of the Pacific saury (Cololabis saira). ICES Journal of Marine Science, 68, 1105-1113. https://doi.org/10.1093/icesjms/fsr070

USGS (2015). The Landsat Level-1 Data Product 2015.

https://www.usgs.gov/core-sciencesystems/nli/landsat/using-usgs-landsat-level-1-datap $\underline{\text { roduct }}$

Wloczyk, C., Richter, R., Borg, E., \& Neubert, W. (2006). Sea and Lake Surface Temperature Retrieval from Landsat Thermal Data in Northern Germany. International Journal of Remote Sensing, 27, 2489-2502. https://doi.org/10.1080/01431160500300206 